\title{
THE EFFECT OF WATER STRESS ON THE GAS EXCHANGE PARAMETERS, PRODUCTIVITY AND SEED HEALTH OF BUCKWHEAT (Fagopyrum esculentum MOENCH)
}

\author{
Agnieszka Pszczółkowska, Gabriel Fordoński, Tomasz Kulik, \\ Jacek Olszewski, Krystyna Płodzień, Maciej Łojko \\ Department of Diagnostics and Plant Pathophysiology, University of Warmia and Mazury in Olsztyn, Plac Łódzki 5 \\ $10-727$ Olsztyn, Poland \\ e-mail: agnieszka.pszczolkowska@uwm.edu.pl
}

Received: 14.01.2010

\section{Abstract}

The present pot experiment studied the effect of different soil moisture contents $(60-70 \%$ CWC (capillary water capacity) - control; $30-35 \% \mathrm{CWC}$ - water stress) on buckwheat productivity, the gas exchange parameters and health of buckwheat nuts. It was found that water deficit affected adversely certain biometric features investigated (plant height, number of nuts per cluster) and caused a decrease in seed weight per plant. It was also shown that water stress reduced the values of the investigated gas exchange parameters (photosynthesis rate, transpiration rate, intercellular-space $\mathrm{CO}_{2}$ concentration, and stomatal conductance) relative to the control treatment. Different soil moisture contents did not have a clear effect on fungal colonization of seeds. The multiplex PCR assays did not enable the detection of the genes responsible for mycotoxin synthesis. Under water deficit conditions, an increase was found in the content of albumin and globulin fractions as well as of glutelin fractions.

Key words: buckwheat, gas exchange parameters, health, traditional method, PCR

\section{INTRODUCTION}

In the global healthy food markets, more and more attention is paid to buckwheat. Its seeds are not only a source of many nutrients, but also a source of biologically active compounds not considered to be nutrients (K le packa and Fornal, 2006). Buckwheat nuts can be a valuable source for the production of both functional food and food additives (Troszýnska et al. 2000). In its composition, the fruit of buckwheat contains non-gluten protein with a balanced amino acid composition and a large amount of raw fat in which unsaturated fatty acids are predominant. Moreover, buckwheat kernels contain macro- and micronutrients such as: $\mathrm{Mg}, \mathrm{K}, \mathrm{Cu}, \mathrm{Zn}$, $\mathrm{Fe}$, much needed in the diet, as well as group $\mathrm{B}$ vitamins and antioxidant compounds ( $\mathrm{Hol}$ as ova et al. 2002; Dietrych-S zós tak and S u checki, 2006). Among the biologically active compounds, polyphenols and inositol deserve special attention $(\mathrm{K} l \mathrm{e}$ packa and Fornal, 2006).

The valuable chemical composition of buckwheat nuts gives the possibility of using buckwheat as raw material for the production of functional, medicinal and protective food ( $\mathrm{Kw}$ i a t k ow ski, 2008). Taking into account the above aspects, it seems to be important to ensure optimal conditions for the growth and development of this plant.

Elements such as buckwheat grain yield, yield structure and the chemical composition of seeds are driven by the genotype, weather conditions, agricultural practices and their interrelationships $(\mathrm{Pod} \mathrm{ol} \mathrm{s} \mathrm{k} \mathrm{a,}$ 2006). Water deficit is of essential significance among the abiotic stress factors reducing plant productivity (Skrabka, 1992). Water deficit in plants is caused by the lack of available water in the soil and atmospheric drought often accompanying high temperatures as well as the predominance of the process of transpiration over water absorption (B o c z e k and S z le ndak, 1992; Fordoń s ki et al. 1994). Water deficiency is one of the most important factors reducing crop yields (S tarck et al. 1995; Grzesiuk et al. 1999).

The health of buckwheat grain harvested, which is to be used as raw material for processing, is also of essential significance. The literature $(\mathrm{Grz}$ e s i u k et al. 1999; Ir z y k o w s ka, 2006; P s z c zółk ow s ka, 2008) confirms that cereals are exposed to a number of factors leading to quantitative and qualitative yield losses during the entire growing period. $\mathrm{C} \mathrm{h}$ a $\mathrm{m} \mathrm{pe} \mathrm{il}$ 
et al. (2004) also showed that agricultural produce could be contaminated with toxins during the vegetation period in the field as well as during harvest, storage and transport.

Among pathogens, the fungi of the genus $\mathrm{Fu}$ sarium, which represent a large group of the species posing a serious threat to crop plants across the world, deserve special attention. The fungal species of the genus Fusarium, when colonising agricultural produce, contaminate it with toxins which have an adverse effect on the health of people and animals consuming such products. Numerous species of the genus Fusarium are toxic and produce mycotoxins from the group of trichothecenes, zearalenones and fumonisins (K w a ś $\mathrm{n}$ a et al. 1991; S chilling et al. 1996; Y u, 2000; Edwards , 2004).

The aim of the present study was to determine the effect of water deficit on the morphological features, gas exchange parameters, health, and protein fraction content in buckwheat nuts.

\section{MATERIAL AND METHODS}

The present pot experiment was carried out in a greenhouse of the University of Warmia and Mazury in Olsztyn in the period $2004-2005$, in quadruplicate. The study object was buckwheat cv. Kora. Buckwheat was grown in Kick-Brauckmann pots. The pots were filled with typical brown soil with the following nutrient availability: $\mathrm{P}_{2} \mathrm{O}_{5}-64.1 \mathrm{mg} \times 100 \mathrm{~g}^{-1}$ of soil, $\mathrm{K}_{2} \mathrm{O}$ $-13.0 \mathrm{mg} \times 100 \mathrm{~g}^{-1}, \mathrm{Mg}-19 \mathrm{mg} \times 100 \mathrm{~g}^{-1}$ and $\mathrm{pH}^{2}$ in $1 \mathrm{~N} \mathrm{KCl}-6.78$. After emergence 10 plants per pot were left. During the growing process, the plants were fed with Hoagland's medium.

The experimental factors were as follows:

Soil moisture:

1. $60-70 \%$ of capillary water capacity (control).

2. $30-35 \%$ of capillary water capacity from the full flowering stage (water stress).

The plants were watered with distilled water 2-3 times per day, controlling soil moisture with a soil moisture meter in accordance with the methodological assumptions.

The scope of the study covered the following:

1. To determine more important biometric features of the plants and seed weight per plant.

2. To determine the gas exchange parameters using a LI-COR 6400 portable photosynthesis system. The determinations were performed at a constant $\mathrm{CO}_{2}$ concentration of $400 \mathrm{ppm}$ and a light intensity of $1000 \mu \mathrm{mol} \mathrm{m} \mathrm{m}^{-2} \times \mathrm{s}^{-1}$. The source of photons was a LED light source emitting light with the main peak wavelength of $670 \mathrm{~nm}$ and the lower peak wavelength of $465 \mathrm{~nm}$. The measurements were made three times (at the following stages: beginning of flowering, full flowering, nut formation) on the youngest fully developed leaf. The results of the abovementioned measurements were averaged. Each measurement was repeated ten times.

3. To evaluate seed health using the traditional method and PCR after prior DNA isolation.

In order to evaluate seed health using the traditional method, samples of 100 nuts each were randomly selected, then the seeds were surface sterilized with $70 \%$ ethanol and $1 \%$ sodium hypochlorite as well as they were washed three times in sterile distilled water. The material so prepared was plated on Petri dishes with solidified PDA medium. The dishes with the kernels placed on them were stored in a laboratory oven at a temperature of $20-23^{\circ} \mathrm{C}$ for $7-10$ days, and subsequently the grown fungal cultures were identified to genus and species based on the morphological features under an optical microscope, using the available monographic studies of Ellis (1971) and Kw a ś n a et al. (1991).

To perform the PCR and multiplex PCR assays, DNA isolation was first carried out using the column method (K u lik et al. 2007) and next, in order to detect more important pathogens of the genus Fusarium (Fusarium culmorum, Fusarium graminearum, Fusarium poae, Fusarium sporotrichioides) in the seeds, in the PCR reaction there were used species-specific primers, available in the literature ( $\mathrm{H} \mathrm{u}$ e et al. 1999; Kulik et al. 2004; Kulik, 2008; Pszczółkowska, 2008), and appropriately selected thermal profiles. The potential toxin-producing ability (the ability to produce trichothecenes, NIV and DON chemotypes as well as enniatins) of the species of Fusarium spp. was determined, using the specific primers for the genes determining mycotoxin synthesis (E d w a rd s et al. 2001; Chandler et al. 2003; Kulik et al. 2007). The PCR reaction mixture comprised the following: FailSa$\mathrm{fe}^{\mathrm{TM}}$ PCR 2X Premix E, 0.2U polymerases Fail Safe ${ }^{\mathrm{TM}}$ Enzyme Mix Only, a primer mix; $5.75 \mu$ of deionized water and $5 \mu$ of template DNA. The samples prepared for the PCR analysis were subjected to cyclical temperature changes in a Mastercycler Gradient thermal cycler (Eppendorf). In each case, the PCR reaction was performed in duplicate.

In order to perform electrophoresis, $1.5 \%$ agarose gel was prepared with an addition of ethidium bromide. Electrophoresis was carried out in an electric field with a voltage of $50 \mathrm{~V}$ for 1.5 hours. The PCR product size was estimated by comparing it to a molecular weight marker - Step Ladder 50 bp (Sigma-Aldrich, USA).

4. To determine protein fraction content in buckwheat seeds.

A $3 g$ seed sample was ground in an IKA A10 laboratory mill (Labortechnik) in such a manner so 


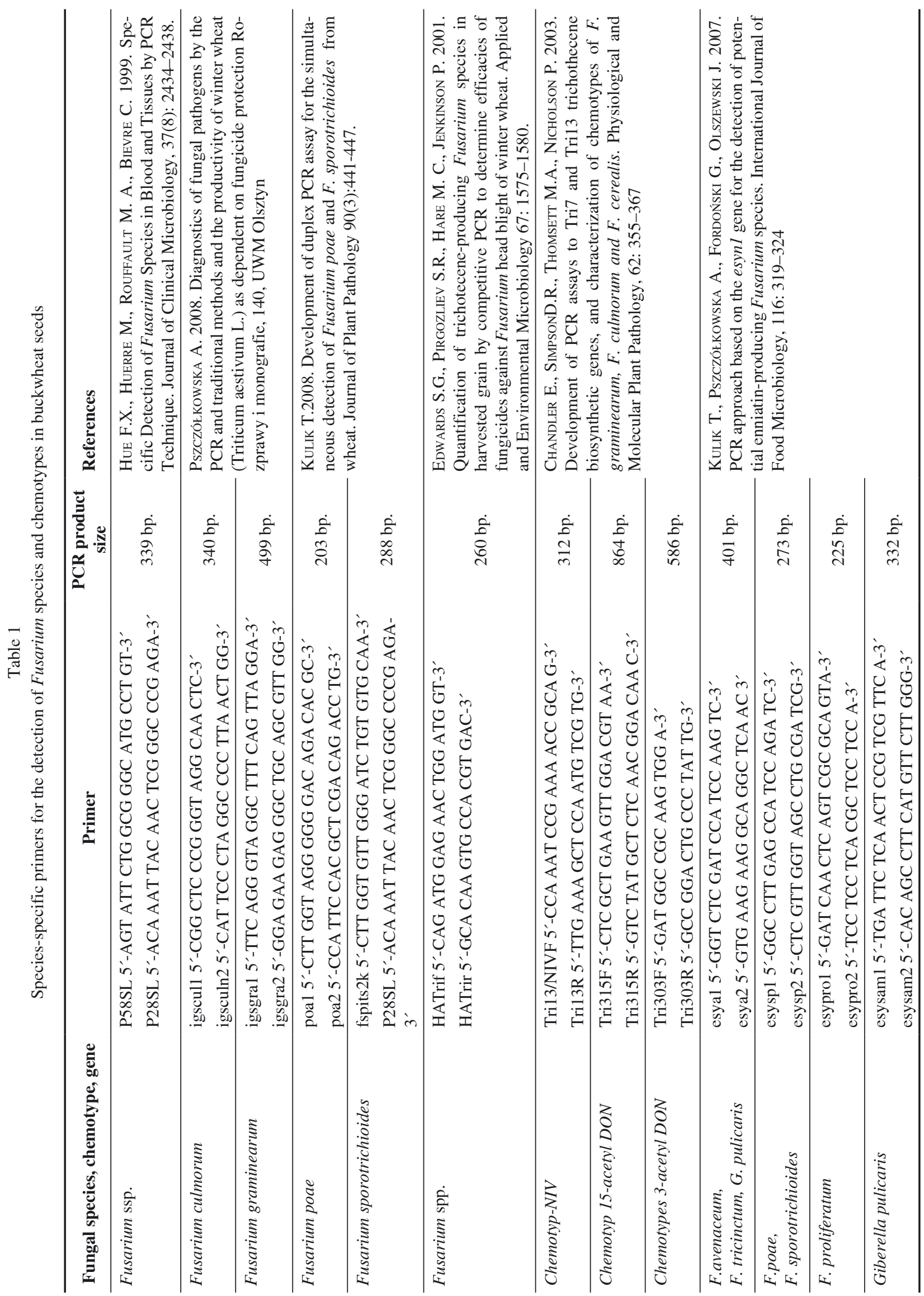


that all particles could be sieved through a $400 \mu \mathrm{m}$ mesh sieve (particles smaller than $250 \mu \mathrm{m}$ accounted for $90 \%$ ). The samples were degreased with petroleum ether in Soxhlet extractors (16 hours). After evaporation of the solvent, $100 \mathrm{mg}$ portions of powder were weighed and placed in Eppendorf tubes, and then three protein fractions were extracted according to $\mathrm{W}$ i e s e $\mathrm{r}$ et al. (1998).

1. Albumins + globulins - triple extraction of $1 \mathrm{~cm}^{3}$ of the mixture $(0.4 \mathrm{~mol} / \mathrm{L} \mathrm{NaCl}+0,067 \mathrm{~mol} / \mathrm{L} \mathrm{HKNa}-$ $\mathrm{PO}_{4}(\mathrm{pH} 7.6)$

2. prolamins - triple extraction of $1 \mathrm{~cm}^{3}$ of the mixture (60\% ethanol)

3. glutelins - double extraction of $1 \mathrm{~cm}^{3}$ of the mixture (50\% propanol- $1+2 \mathrm{~mol} / \mathrm{L}$ urea $0.05 \mathrm{~mol} / \mathrm{L}$ Tris $\mathrm{HCl}(\mathrm{pH} 7.5)+1 \%$ DTE under nitrogen.

The first two protein fractions were extracted at room temperature using an Eppendorf thermomixer (10-minute extraction). Glutelins were extracted at a temperature of $60^{\circ} \mathrm{C}$ in the thermomixer. After each extraction, the mixture was centrifuged at $11000 \mathrm{x}$ g. The collected fractions were lyophilized and then dissolved in $2 \mathrm{~cm}^{3}$ of the respective phase (1-3), cleaned through a Spartan $-3 \mathrm{NY}$ filter with a $0.45 \mu \mathrm{m}$ mesh and transferred to glass vials. The determinations were made using a Hewlett Packard Series 1050 system with the following parameters: column RP-18 Vydac 218TPP54, $5 \mu \mathrm{m}, 250 \times 4.6 \mathrm{~mm}$, pre-column Zorbax 3000SB-C18 4.6x12.5 mm, column temperature $45^{\circ} \mathrm{C}$, mobile phase flow rate $1 \mathrm{ml} / \mathrm{min}$, injection size $20 \mu \mathrm{l}$. The separation was performed using a two-component gradient. The proportion of component A: 0 min $75 \%$, $5 \min 65 \%, 10 \min 50 \%, 17 \min 25 \%, 18 \min 15 \%$, $19 \min 75 \%$. The first gradient (A) was water with an addition of $0.1 \%$ TFA, the second gradient (B) was ACN with an addition of $0.1 \%$ TFA. The detection was carried out using a detector manufactured by the same company, and the reading was done at a wavelength of $210 \mathrm{~nm}$.

The results were analysed based on HPLC 3D Chem Station software (Hewlett Packard).
The assays were carried out at the Department of Processing and Chemistry of Plant Raw Materials, Faculty of Food Sciences, University of Warmia and Mazury in Olsztyn.

\section{RESULTS AND DISCUSSION}

Atmospheric conditions during plant growth and development have a decisive influence on productivity. This is confirmed by Pod ols k a (2006) in her study in which she indicates that the lowest buckwheat yields were obtained in the year in which the third decade of May was characterized by a shortage of rainfall and high air temperature, which in effect prolonged buckwheat emergence and inhibited its initial growth. In the same year, the flowering and nut set period also occurred when there was a very small amount of rainfall and high temperature.

Among the investigated biometric features of buckwheat cv. Kora, a significant decrease was found in seed weight per plant, number of nuts per cluster and plant height under water deficit conditions (Table 2). Li s z e w s k i (2002) also reports that summer drought does not have a beneficial effect on buckwheat seed set and filling, while O ls zew ski et al. (2007) showed that water deficit and high temperature in a greenhouse had an adverse impact on some elements of the wheat yield structure and productivity.

Water stress resulted in a reduction of the gas exchange parameters both in the first and second year of the study. A decrease in the rates of photosynthesis and transpiration as well as in intercellular-space $\mathrm{CO}_{2}$ concentration and stomatal conductance was shown under water deficit conditions relative to the control (Tables 3 and 4). In the domestic and foreign literature, there are no data on the effect of different soil moisture contents on the gas exchange parameters in buckwheat. However, Olszewski et al. $(2007,2008)$ and Pszczółkowska et el. (2003) indicate the adverse influence of water deficit on the gas exchange parameters in wheat, pea and yellow lupin.

Table 2

Selected biometric features of buckwheat cv. Kora under water stress conditions (means of $2004-2005$ )

\begin{tabular}{cccccccc}
\hline Cultivar & $\begin{array}{c}\text { Soil water } \\
\text { capacity, } \%\end{array}$ & $\begin{array}{c}\text { Plant height, } \\
\mathrm{cm}\end{array}$ & $\begin{array}{c}\text { Number of } \\
\text { branches }\end{array}$ & $\begin{array}{c}\text { Number of } \\
\text { clusters per plant }\end{array}$ & $\begin{array}{c}\text { Number of nuts } \\
\text { per cluster }\end{array}$ & $\begin{array}{c}\text { Thousand seed } \\
\text { weight (g) }\end{array}$ & $\begin{array}{c}\text { Seed weight } \\
\text { per plant, g }\end{array}$ \\
\hline & $60-70 \%$ & $136.17 \mathrm{~b}$ & $2.60 \mathrm{a}$ & $23.59 \mathrm{a}$ & $6.00 \mathrm{~b}$ & $29.81 \mathrm{a}$ & $4.20 \mathrm{~b}$ \\
Kora & $30-35 \%$ & $118.55 \mathrm{a}$ & $2.52 \mathrm{a}$ & $24.26 \mathrm{a}$ & $3.67 \mathrm{a}$ & $27.97 \mathrm{a}$ & $2.49 \mathrm{a}$ \\
\hline
\end{tabular}

Homogeneous groups a, ab, b, according Fisher's LSD test 
Table 3

Gas exchange parameters in buckwheat under water stress conditions in 2004

\begin{tabular}{|c|c|c|c|c|c|}
\hline Cultivar & $\begin{array}{l}\text { Capillary water } \\
\text { capacity of soil }\end{array}$ & $\begin{array}{c}\text { Photosynthesis } \\
\left(\mu \mathrm{molCO}_{2} \times \mathrm{m}^{-2} \times \mathrm{s}^{-1}\right)\end{array}$ & $\begin{array}{c}\text { Transpiration } \\
\left(\mathrm{mmolH}_{2} \mathrm{O} \times \mathrm{m}^{-2} \times \mathrm{s}^{-1}\right)\end{array}$ & $\begin{array}{c}\text { Intercellular-space } \mathrm{CO}_{2} \\
\text { concentration } \\
\left(\mu \mathrm{molCO}_{2} \times \mathrm{mol}^{-1}\right)\end{array}$ & $\begin{array}{c}\text { Stomatal } \\
\text { conductance } \\
\left(\mathrm{molH}_{2} \mathrm{O} \times \mathrm{m}^{-2} \times \mathrm{s}^{-1}\right)\end{array}$ \\
\hline \multirow{2}{*}{ Kora } & $60-70 \%$ & $15.10 \mathrm{a}$ & $4.00 \mathrm{a}$ & $269.40 \mathrm{a}$ & $0.31 \mathrm{a}$ \\
\hline & $30-35 \%$ & $6.90 \mathrm{~b}$ & $1.00 \mathrm{~b}$ & $153.60 \mathrm{~b}$ & $0.05 \mathrm{~b}$ \\
\hline
\end{tabular}

Mean values of three measurements (I - measurement of gas exchange parameters at the beginning of flowering;

II - measurement of gas exchange parameters at full flowering; III - measurement of gas exchange parameters at the nut formation stage) Homogeneous groups a, ab, b, according Fisher's LSD test

Table 4

Gas exchange parameters in buckwheat under water stress conditions in 2005

\begin{tabular}{|c|c|c|c|c|c|}
\hline Cultivar & $\begin{array}{l}\text { Capillary water } \\
\text { capacity of soil }\end{array}$ & $\begin{array}{c}\text { Photosynthesis } \\
\left(\mu \mathrm{molCO}_{2} \times \mathrm{m}^{-2} \times \mathrm{s}^{-1}\right)\end{array}$ & $\begin{array}{c}\text { Transpiration } \\
\left(\mathrm{mmolH}_{2} \mathrm{O} \times \mathrm{m}^{-2} \times \mathrm{s}^{-1}\right)\end{array}$ & $\begin{array}{c}\text { Intercellular-space } \mathrm{CO}_{2} \\
\text { concentration } \\
\left(\mu \mathrm{molCO}_{2} \times \mathrm{mol}^{-1}\right)\end{array}$ & $\begin{array}{l}\text { Stomatal conductance } \\
\quad\left(\mathrm{molH}_{2} \mathrm{O} \times \mathrm{m}^{-2} \times \mathrm{s}^{-1}\right)\end{array}$ \\
\hline \multirow[b]{2}{*}{ Kora } & $60-70 \%$ & $14.90 \mathrm{a}$ & $3.00 \mathrm{a}$ & $226.80 \mathrm{a}$ & $0.32 \mathrm{a}$ \\
\hline & $30-35 \%$ & $8.20 \mathrm{a}$ & $1.80 \mathrm{~b}$ & $170.00 \mathrm{a}$ & $0.07 \mathrm{~b}$ \\
\hline
\end{tabular}

Mean values of three measurements ( $\mathrm{I}$ - measurement of gas exchange parameters at the beginning of flowering;

II - measurement of gas exchange parameters at full flowering; III - measurement of gas exchange parameters at the nuts formation stage)

Homogeneous groups a, ab, b, according Fisher's LSD test

Table 5

Number of fungal isolates in buckwheat cv. Kora nuts under water stress conditions in 2004

\begin{tabular}{|c|c|c|}
\hline & Control & Water stress \\
\hline Fungal species & $\begin{array}{c}60-70 \% \text { CWC } \\
60-70 \% \text { of capillary water } \\
\text { capacity }\end{array}$ & $\begin{array}{c}30-35 \% \text { CWC } \\
30-35 \% \text { of capillary water capacity }\end{array}$ \\
\hline 1. Alternaria alternata Keissler Nees & 2 & 1 \\
\hline 2. Cladosporium cladosporioides (Fr.) de Wries & 6 & 8 \\
\hline 4. Chaetomium spp. & 4 & 4 \\
\hline 4. Epicoccum purpureans Link ex Schlecht & & 1 \\
\hline 5. Fusarium poae (Peck) Wollenw. & 2 & \\
\hline 6. Penicillium spp. & 6 & 5 \\
\hline 5. Non-sporulating mycelia & 2 & 4 \\
\hline Total & 22 & 23 \\
\hline
\end{tabular}

CWC - capillary water capacity of soil: $60-70 \%$ - control, $30-35 \%$ - water stress 
Table 6

Number of fungal isolates in buckwheat cv. Kora nuts under water stress conditions in 2005

\begin{tabular}{ccc}
\hline & Control & Water stress \\
\cline { 2 - 3 } Fungal species & $\begin{array}{c}60-70 \% \text { CWC } \\
60-70 \% \text { of capillary water } \\
\text { capacity }\end{array}$ & $\begin{array}{c}30-35 \% \text { CWC } \\
30-35 \% \text { of capillary water capacity }\end{array}$ \\
\hline 1. Alternaria alternata Keissler Nees & 1 & 1 \\
\hline 2. Cladosporium cladosporioides (Fr.) de Wries & & 1 \\
\hline Total & 1 & 1 \\
\hline
\end{tabular}

CWC - capillary water capacity of soil: $60-70 \%$ - control, $30-35 \%$ - water stress

Fungal colonisation of buckwheat cv. Kora seeds was at a similar level in the first year of the study. 22 fungal isolates were identified in the control seeds and 23 isolates in the water stress treatment (Table 5). Among the pathogenic fungi, the presence of Fusarium poae was only found in the control, while among the saprophytic fungi, the species of Cladosporium cladosporioides and the fungi of the genus Penicillium were predominant. Under water stress conditions, the species of Cladosporium cladosporioides and the fungi of the genera Penicillium and Chaetomium were found in greatest numbers. But the year 2005 was not favourable for the development of the fungi on buckwheat nuts. The presence of only 1 fungal isolate was found in the control treatment and 1 isolate under water deficit conditions. Both identified fungal cultures belonged to the saprophytic species (Table 6). The study of Wachowska and Kwiatkowski (2006) also confirms the presence of hyphal fungi of the genera Cladosporium, Penicillium and Aspergillus on nuts of buckwheat grown under different harvesting options.

Problems associated with the presence of fusariotoxins in cereals and other products of natural origin may occur in Poland (Ch ełk ow ski, 1985). When colonizing agricultural produce, the fungi of the genus Fusarium contaminate it with toxins which have an adverse effect on the health of people and animals consuming such products. Many species of the genus Fusarium are toxic and produce mycotoxins from the group of trichothecenes, zearalenones, fumonisins, and enniatins (Y u, 2000; Edwards, 2004; K u lik et al. 2007).

In this study, the presence of Fusarium spp. was found, using the PCR method, in buckwheat nuts obtained from the plants with respect to which optimal soil moisture conditions were applied during the growing period in the second year of the study (Tab. $7)$. The results obtained by applying the specific primers for four fungal species of the genus Fusarium showed only the presence of Fusarium poae in the water stress-treated seeds in the first year of the study. The pair of poa1/poa2 primers used in the investigations generated a 203-bp product in accordance with the results obtained by Kulik (2008). A negative result was obtained in the multiplex PCR reaction using the specific primers for the genes responsible for the production of mycotoxins from the group of trichothecenes and enniatins. This demonstrates that the buckwheat grain assayed was free from secondary fungal metabolites - mycotoxins - and that it was safe raw material which could be used for functional food production.

As a result of the effect of a pathogen or other environmental stresses on a plant, protein synthesis and accumulation occur. These can be enzymatic, structural, signal proteins, with the properties of metabolic inhibitors, as well as protective proteins with regard to the cell structures, called stress proteins $(\mathrm{K} \mathrm{o} \mathrm{z} ł$ o w ska and Konieczny, 2003).

In the present study, an increase was found in the content of albumin + globulin fractions and glutelin fractions under water deficit conditions (Fig. 1). K o n o p k a et al. (2007) also reports that water stress is one of the stresses which affect changes in amount of protein fractions. Dietrych-Szóstak et al. (2008) showed that the delayed sowing date caused a decrease in buckwheat yield and TSW (thousand seed weight), but an increase in protein content. 


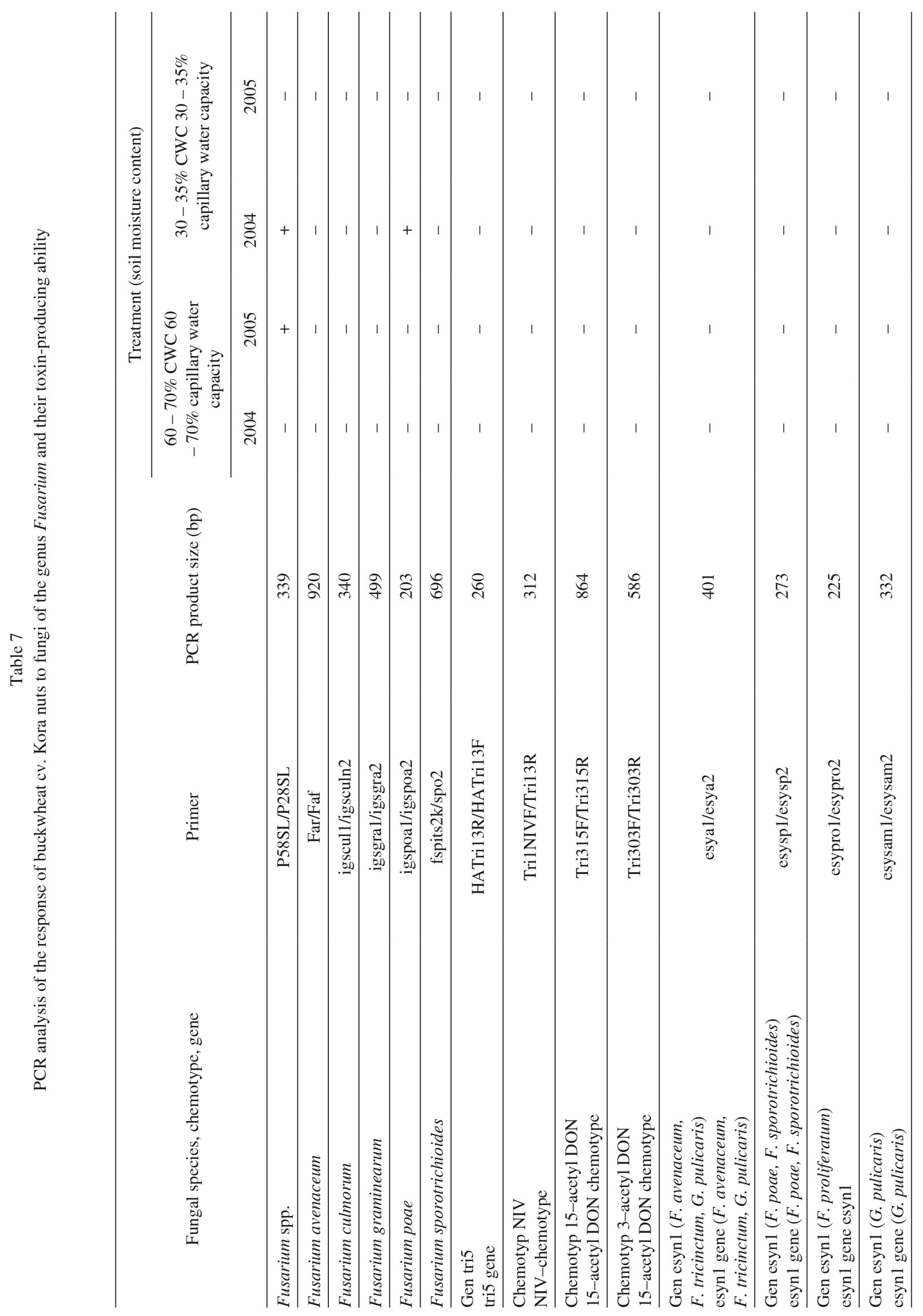




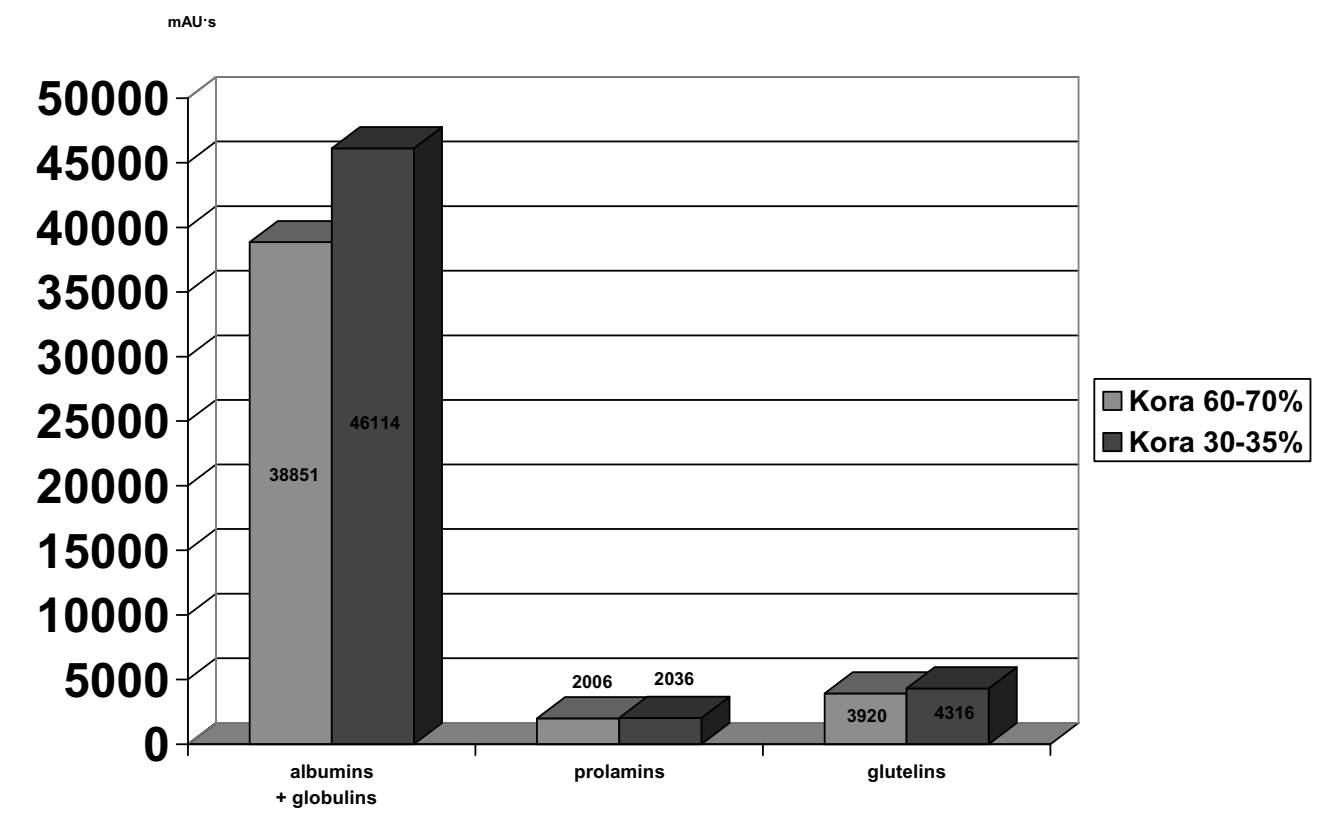

Fig. 1. Protein fraction content in buckwheat nuts obtained from plants grown under different soil moisture conditions (calculated as $\mathrm{mAU} \times \mathrm{s}$ )

\section{CONCLUSIONS}

1. Water deficit affected adversely some biometric features (plant height, number of nuts per cluster) and caused a decrease in seed weight per plant.

2. Water stress resulted in a significant reduction in the investigated gas exchange parameters (photosynthesis rate, transpiration rate, intercellular-space $\mathrm{CO}_{2}$ concentration, and stomatal conductance) relative to the control treatment, in particular in the first year of the study.

3. Different soil moisture contents did not have a clear effect on fungal colonization of seeds.

4. The results of the multiplex PCR reaction did not show the presence of homologs of the genes responsible for mycotoxin production.

5. Under water deficit conditions, an increase was found in the content of albumin and globulin fractions as well as of glutelin fractions.

\section{REFERENCES}

B oczek J., Szlendak E., 1992. Wpływ stresów roślinnych na porażenie roślin przez szkodniki. / The effect of plant stresses on infection of plants by pests. / Post. Nauk Rol. 2/237: 1-17.

Champeil A., Doré T., Fourbet J. F., 2004. Fusarium head blight: epidemiological origin of the effects of cultural practices on head blight attacks and the production of mycotoxins by Fusarium in wheat grains. Plant Sci. 166: $1389-1415$.
Chandler E., A., Simpson D. R., Thomsett M. A., Nichols on P., 2003. Development of PCR assays to Tri7 and Tri13 trichothecene biosynthetic genes, and characterization of chemotypes of $F$. graminearum, F. culmorum and F. cerealis. Physiol. and Molecular Plant Pathol., 62(6): 355-367

Chełkowski J., 1985. Mikotoksyny, wytwarzające je grzyby i mikotoksykozy. SGGW, Warszawa.

Dietrych-Szóstak D., Podolska G., Maj L., 2008. The effect of $\mathrm{N}$ fertilization on buckwheat yield and content of protein and flavonoids in buckwheat nuts. Fragm. Agronom. 1(97): 101-109.

Dietrych-Szóstak D., Suchecki Sz., 2006. Flavonoids and some mineral components content in buckwheat seed of polish varieties. Fragm. Agronom. 23 (89): 45-56.

Edwards S. G., 2004. Influence of agricultural practices on Fusarium infection of cereals and subsequent contamination of grain by trichothecene mycotoxins. Toxicology Letters 153: 29-35.

Edwards S. G., Pirgozliev S. R., Hare M. C., Jenkin s on P., 2001. Quantification of trichotecene-producing Fusarium species in harvested grain by competitive PCR to determine efficacies of fungicydes against Fusarium head blight of winter wheat. Applied and Environ. Microbiol. 67 (4): 1575-1580.

E11 is M. B., 1971. Dematiaceous Hyphomycetes. Commonwealth Mycological Institute Kew, Surrey, England.

Fordoński G., Górecki R. J., Bieniaszewski T., Majchrzak B., 1994. Effect of thiuram on legume seed germination, vigor and seedling wholesomeness under chilling stress. Mat. Konf. Uszlachetnianie 
Materiałów Nasiennych. PAN, ART Olsztyn, 1994: 81-88.

Grzesiuk S., Koczowska I., Górecki R. J. 1999. Fizjologiczne podstawy odporności roślin na choroby. / The physiological basis for plant resistance to diseases. Wyd. 2. ART, Olsztyn: 274.

Holasova M., Fiedlerova V., Smrcinova H., Orsak M., Lachman J., Vavreinova S., 2002. Buckwheat - the source of antioxidant activity in functional foods. Food Research Inter. 35: 207-211.

Hue F. X., Huerre M., Rouffault M. A., Bievre C., 1999. Specific Detection of Fusarium Species in Blood and Tissues by PCR Technique. J. Clinic. Microbiol. 37 (8): 2434-2438.

Ir zykowska L., 2006. Molecular markers in diagnostics of cereal foot rot and root diseases. Post. Nauk Rol. 6: 31-39.

K lepacka J., Fornal Ł., 2006. Bioactive components of buckwheat and its prohealth function (Review article). Fragm. Agronom. (89): 78-92.

Konopka I., Tańska M., Pszczółkowska A., Fordoński G., Kozirok W., Olszewski J., 2007. The effect of water stress on wheat kernel size, color and protein composition. Pol. J. Natur. Sci. 22(2): $157-171$

Kozłowska M., Konieczny G., 2003. Biologia odporności roślin na patogeny i szkodniki / The biology of plant resistance to pathogens and pests: 173 .

K u lik T., 2008. Development of duplex PCR assay for the simultaneous detection of $F$. poae and $F$. sporotrichioides from wheat. J. Plant Pathology, 90 (3): 441-447.

Kulik T., Fordoński G., Pszczółkowska A., Płodzień K., Łapiński M., 2004. Development of PCR assay based on ITS2 rDNA polymorphism for the detection and differentiation of Fusarium sporotrichioides. FEMS Microbiol. Letters 239: 181-186.

Kulik T., Pszczółkowska A., Fordoński G., Olszewski J., 2007. PCR approach based on the esyn1 gene for the detection of potential enniatin-producing Fusarium species. Inter. J. Food Microbiol. 116: 319324.

Kwaśna H., Chełkowski J., Zajkowski P., 1991. Grzyby. Tom XXII. / Fungi. Volume XXII. / (Flora Polska). PAN Instytut Botaniki Warszawa - Kraków.

Kwiatkowski J., 2008. Influence of growth regulators on chemical composition in nuts of polish buckwheat cultivars. Fragm. Agronom. 1 (97): 210-219.

Liszewski M., 2002. The effect of foliar application of boron, sowing dates and rates on the morphological features of shoot and buckwheat fruiting. Acta Agr. Silv. Ser. Agri. 41: 13-21.

Olszewski J., Pszczółkowska A., Kulik T., Fordoński G., Płodzień K., Okorski A., Wasielewska J., 2008. Rate of photosynthesis and winter wheat leaves and ears under water deficit conditions. Pol. J. Natur. Sci. 23 (2): 326-335.

Olszewski J., Pszczółkowska A., Kulik T., Fordoński G., Płodzień K., Okorski A., Wasielewska J., 2007. Effect of water deficit on gas exchange parameters, productivity and grain health of winter whet cultivars. Acta Sci. Pol. Ser. Agri. 6 (4): 33-42.

Podolska G., 2006. Weed control in buckwheat and its effect on yield. Fragm. Agronom. 1 (89): 161-173.

P s z c z ółk ow ska A., 2008. Diagnostics of fungal pathogens by the PCR and traditional methods and the productivity of winter wheat (Triticum aestivum L.) as dependent on fungicide protection. Rozprawy i Monografie, 140: 142 .

Pszczółkowska A., Olszewski J., Płodzień K., Kulik T., Fordoński G., Żuk-Gołaszewska K., 2003. Effect of the water stress on productivity of selected genotypes of pea (Pisum sativum L.) and yellow lupin (Lupinus luteus L.). Electronic J. of Polish Agric. Univ. Ser. Agronomy, 6 (1): www.ejpau.media. $\mathrm{pl} /$ volume6/issue1/agronomy/art-02.html

Schilling A. G., Möller E. M., Geiger H. H., 1996. Polymerase chain reaction - based assays for species - specific detection of Fusarium culmorum, F. graminearum, and $F$. avenaceum. Phytopathology, 86 (5): 515-523.

Skrabka H., 1992. Roślina a środowisko. Wybrane działy z fizjologii rosslin. Skrypt / The plant and the environment. Selected issues of plant physiology. Manuscript. AR Wrocław.

St arck Z., Chołuj D., Niemyska B., 1995. Fizjologiczne reakcje roślin na niekorzystne czynniki środowiska. / Physiological responses of plants to adverse environmental factors. SGGW, Warszawa.

Troszyńska A., Honke J., Kozłowska H. 2000. Natural non-nutrients of plant origin as the components of functional food. Post. Fiti. 2: 17-22.

Wachowska U., Kwiatkowski J. 2006. Microorganisms on buckwheat nuts in different variants of harvest. Fragm. Agronom. 1(89): 211-219.

Wieser H., Antes S., Seilmeier W. 1998. Quantitative determination of gluten protein types in wheat flour by reversed-phase high-performance liquid chromatography. Cerael Chem., 75 (5): 644-650.

Wożny A., Michejda J., Ratajczak L. (red.), 2000. Podstawy biologii komórki roślinnej. Wydawnictwo Akademii Medycznej, Poznań.

Y u J., 2000. Fungi, fungal spores, mycotoxins and food safety: molecular genetics approaches. Food Res. Inst. Ann. Report. Mycotoxins Univ. of Wisconsin, Medison, USA: $40-46$. 


\section{Wpływ stresu wodnego na wskaźniki wymiany gazowej, produktywność i zawartość grzybni (Fagopyrum esculentum)}

\section{Streszczenie}

W przeprowadzonym doświadczeniu wazonowym badano wpływ zróżnicowanego uwilgotnienia gleby $(60-70 \% \mathrm{kpw}$ - kontrola; $30-35 \% \mathrm{kpw}$ - stres wodny) na plonowanie, wskaźniki wymiany gazowej oraz zdrowotność orzeszków gryki. Stwierdzono, że deficyt wodny wpłynął niekorzystnie na niektóre badane cechy biometryczne (wysokość roślin, liczba orzeszków w gronie) oraz spowodował zmniejszenie masy orzeszków z rośliny. Wykazano również, że stres wodny obniżył intensywność badanych wskaźników wymiany gazowej (intensywność procesu fotosyntez, transpiracji, stężenie międzykomórkowe $\mathrm{CO}_{2}$, przewodność szparkowa) w stosunku do obiektu kontrolnego. Zróżnicowane uwilgotnienie podłoża nie wpłynęło jednoznacznie na zasiedlenie nasion przez grzyby. Analizy multiplex PCR nie umożliwiły wykrycia genów odpowiedzialnych za syntezę mikotoksyn. W warunkach niedoboru wody stwierdzono wzrost zawartości frakcji albuminy i globuliny oraz glutelin. 